\title{
Seasonal and interannual variability of zooplankton community in waters off Mallorca island (Balearic Sea, Western Mediterranean): 1994-1999
}

\section{Variabilité saisonnière et interannuelle du zooplancton au large de Majorque (mer des Baléares, Méditerranée occidentale)}

\author{
Mauz Fernández de Puelles *, Jean-Michel Pinot, Joaquin Valencia \\ Instituto Español de Oceanografia, Centro de Baleares, Apartado 291, 07080 Palma de Mallorca, Spain
}

Received 28 March 2003; revised and accepted 1 July 2003

\begin{abstract}
During 1994-1999, the mesozooplankton community was sampled monthly in the upper sea layer (up to $100 \mathrm{~m}$ ) along a cross-shelf transect of three stations in waters off Mallorca island. Copepods formed the most abundant group (54\%) followed by appendicularians (17\%), cladocerans and meroplankton larvae (13\%). The abundance of all these groups decreased in the offshore direction but it was not the case for other zooplankton groups. A clear seasonal cycle was evident consisting of a general decrease of the abundance from the beginning to the end of the year. In addition to the general increase during late winter and spring, an absolute maximum was detected in May, particularly important at the neritic station and a relative maximum in March and October. During this annual cycle, the community structure was almost maintained. An interannual trend was also present, characterized by an overall decrease in the total zooplankton abundance from 1994 to 1999. Concurrent measurements of water and air temperature show that this trend was correlated with a warming of coastal waters of atmospherical origin. In particular, a marked minimum in zooplankton abundance was recorded during 1998, which was the warmest year registered. During 1997-1998, the warming was also associated with the presence of fresh, nutrient-poor southern waters of Atlantic origin.
\end{abstract}

(C) 2003 Éditions scientifiques et médicales Elsevier and Ifremer/CNRS/IRD. All rights reserved.

\section{Résumé}

De 1994 à 1999, la communauté superficielle du mésozooplancton des cent premiers mètres a été échantillonnée le long d'une radiale de trois stations au large de Majorque. Les copépodes représentent le groupe le plus abondant (54\%) suivi des appendiculaires (17\%), des cladocères et des larves de méroplancton (13\%). L'abondance de ces groupes décroît au fur et à mesure que l'on s'éloigne de la côte, ce qui n'est pas le cas pour les autres groupes de zooplancton. Le cycle saisonnier est très marqué, avec une diminution générale de l'abondance entre le début et la fin de l'année. L'augmentation pendant la première moitié de l'année est marqué par un maximum détecté au printemps, particulièrement important au niveau de la station néritique, et un maximum relatif pendant l'hiver et l'automne. Cet écart s'amoindrit cependant au large. On remarque une tendance interannuelle caractérisée par une diminution générale de l'abondance totale du zooplancton entre 1994 et 1999. Des mesures de la température de l'eau et de l'air démontrent que cette tendance est liée à un réchauffement d'origine atmosphérique des eaux du plateau continental. En 1998, l'année la plus chaude, on a enregistré un minimum important de l'abondance du zooplancton. En 1997 et 1998, les températures élevées étaient liées à la présence de masses d'eau plus chaude venue du sud, moins riches en sels nutritifs et d'origine Atlantique.

() 2003 Éditions scientifiques et médicales Elsevier SAS and Ifremer/CNRS/IRD. All rights reserved.

Keywords: Balearic Sea; Copepods; Hydrography; Zooplankton; Western Mediterranean

Mots clés : Mer des Baléares ; Copépodes ; Hydrolique ; Zooplancton ; Méditerranée occidentale

* Corresponding author.

E-mail address: mluz.fernandez@ba.ieo.es (M. Fernández de Puelles). 


\section{Introduction}

The Balearic Sea is a transition marine region of the Western Mediterranean where water masses of southern and northern origins meet in the surface $(0-100 \mathrm{~m})$ layer. Cool and salty northern waters proceeding from the Gulf of Lions where strong winds are frequent, encounter warmer, fresher waters of Atlantic origin flowing northward from the southern Algerian basin where weather conditions are milder (Font et al., 1988; García et al., 1994). The Balearic Islands ridge represents a complex topographical barrier separating these two basins. The water exchange takes place in two channels: the Ibiza Channel, between Ibiza and the Spanish peninsula, and the Mallorca Channel between Ibiza and Mallorca. Pinot et al. (2002) have recently shown that the Mallorca channel is the preferred route of southern waters in their northward spread. Nevertheless, the circulation can be reversed during winter and spring as cool, southward-flowing waters of northern origin reach the channel.

On the other hand, the interannual variability of plankton is high in relation to the environment and long time-series are deeply recommended in the marine ecosystem (Colebrook, 1978, 1985). Few time series of zooplankton abundance have been collected in the western Mediterranean Sea. Mazzocchi and Ribera d'Alcalá (1995) and Christou (1998), who analyzed the main zooplankton groups, particularly copepods in the Thyrrenian and the Aegean Sea, respectively, found significant seasonal and interannual variability in their abundance. The seasonal and interannual variability of zooplankton sampled in the coastal areas of the Ligurian Sea, the Gulf of Lions, the Adriatic Sea and the Aegean Sea was described by Gaudy (1985), Razouls and Kouwenberg (1993), Baranovic et al. (1993) and Siokou-Frangou (1996), respectively. But these marine regions differ much from the Balearic Sea and the point of view of oceanic and meteorological conditions. Studies describing the time variability of zooplankton abundance in the Balearic Sea are of course even fewer and did not allow to evidence fluctuations at large time scales (Vives, 1966; Fernández de Puelles et al., 1997). This is with the main purpose of improving our knowledge of the seasonal and interannual variability of zooplankton abundance in the Mediterranean that the study was conducted. We also aimed at establishing the impact of hydrographic forcing on zooplankton. We considered that the Mallorca Channel is a transition zone where any tendency will be better reflected by the hydrographic variables and its influence on zooplankton and an adequate place for a long-term monitoring. Due to its geographical location in the Balearic basin, this channel could be representative of the deep-sea marine environment of the central Western Mediterranean. Monthly cruises were carried out in order to resolve the seasonal scale. The three sampling locations were located along a cross-shelf transect to investigate the zooplankton variability from neritic to oceanic area. These stations are not affected by river discharge nor pollutants of terrestrial origin, and it is important to underline that in spite of their location in a shelf region, they are more influenced by the open ocean circulation conditions of the Algero-Balearic basin than by the typical coastal circulation conditions as those at play in shelf areas of the Spanish peninsula for example.

In this paper, we first describe the study, the material and the techniques used to collect the biological and physical data and after that, we show the correlations between the environmental, physico-chemical variables, ocean temperature and salinity, nitrates concentration and air temperature. Moreover, we analyze the zooplankton community and the variability of the main groups observed in relation to the environmental variables and the hydrography of the studied area is established. Finally, concerning to the global warming climate we notify the dramatic consequences that might have on the zooplankton of the Western Mediterranean.

\section{Materials and methods}

From January 1994 to January 2000, three stations, respectively, 75, 100 and $200 \mathrm{~m}$ depth, located along a transect reaching the shelf-break over the southern shelf of Mallorca, were visited monthly at 9:30, 11:00 and 12:00 h, respectively, in every cruise (Fig. 1). Mesozooplankton was sampled using a Bongo Plankton net with a $250 \mu \mathrm{m}$ mesh by means of oblique hauls between $100 \mathrm{~m}$ depth and the surface, except at station $1(75-0 \mathrm{~m})$. CTD casts were carried out at each station with a SeaBird-19 probe. Water samples were obtained with Niskin bottles of 51 at depths $0,15,25,50,75,100,125$ and $200 \mathrm{~m}$ for physical and chemical laboratory analyses. Nitrates concentrations were estimated by using a Technicon AAII Analyzer (Armstrong et al., 1967).

For taxonomic studies, zooplankton samples were fixed in $4 \%$ neutralized formaldehyde buffered with borax. Biomass samples were frozen at $-20{ }^{\circ} \mathrm{C}$ and later analyzed by gravimetric methods (Lovegrove, 1966), giving the data as mg of dry weight $\mathrm{m}^{-3}$. Subsamples were obtained for numerical abundance using a Folsom plankton splitter and an adequate statistical treatment (Postel et al., 2000). Simple linear regression statistics and Anova analyses were used to quantify the relationship between biomass and zooplankton abundance at each station for the different groups. In order to define year groupings, cluster analysis were carried out using the Bray-Curtis similarity index and squared root data transformation. The analysis was performed using the PRIMER program (Plymouth Marine Laboratory, UK).

Monthly averages of air temperature were obtained from the Spanish Meteorological Institute from data recorded at a coastal station located in the harbor of Palma de Mallorca, $20 \mathrm{~km}$ apart from station 1 .

\section{Results}

\subsection{Environmental factors}

The most obvious signal in temperature was the seasonal cycle characterized by winter cooling and summer warming 


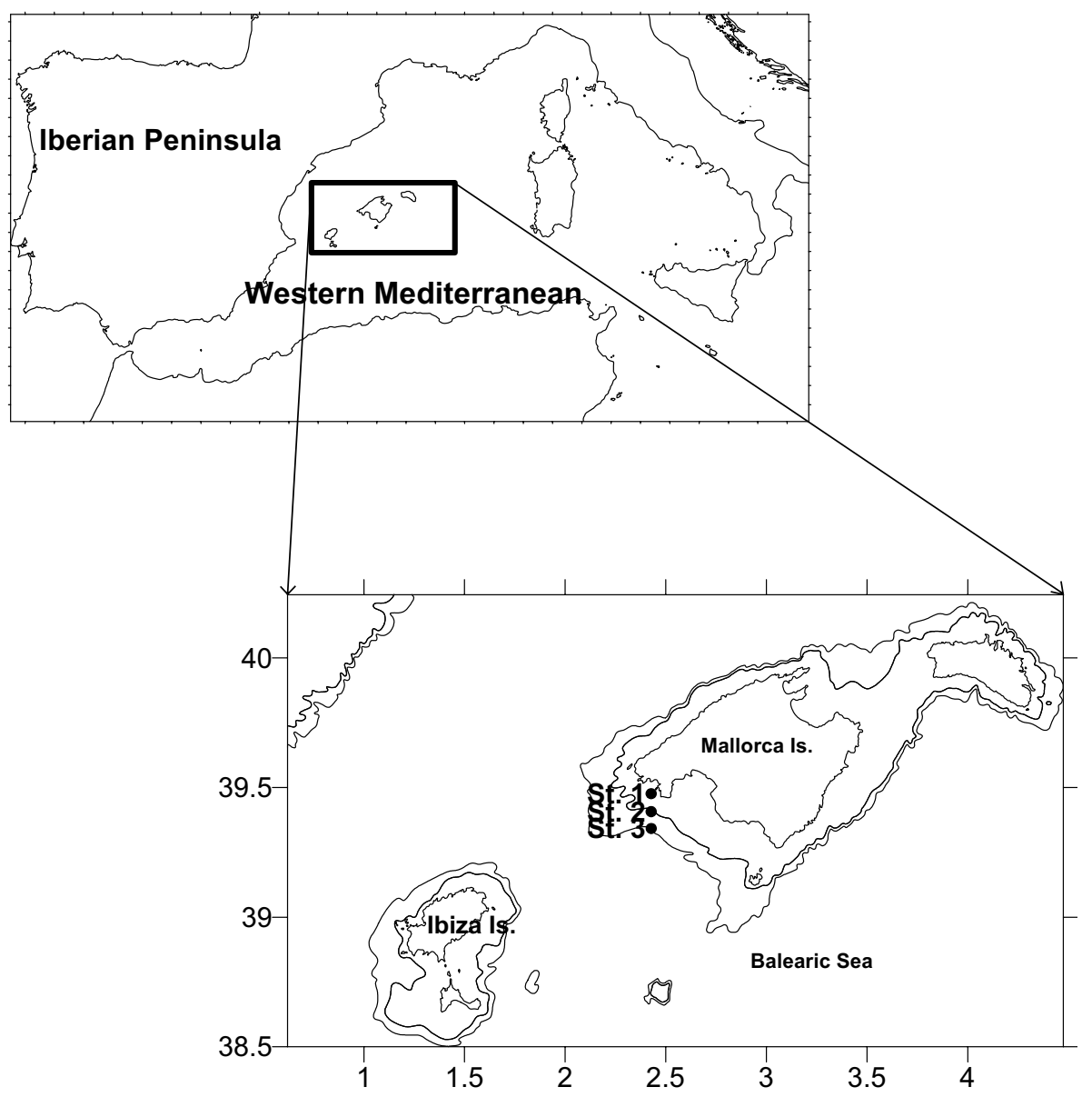

Fig. 1. Locations of sampled stations to the south-west of Mallorca (Balearic Sea).

(Fig. 2a). This cycle was very similar at all three stations. The sea surface temperature was the lowest, $13.5^{\circ} \mathrm{C}$, in February-March and the highest, up to $28^{\circ} \mathrm{C}$, in August-September. This seasonal signal was still detectable at $100 \mathrm{~m}$ depth but was not observed at $200 \mathrm{~m}$. Strong stratification developed between May and October in the upper $50 \mathrm{~m}$ whereas winter months were characterized by the formation of a well mixed layer reaching $100 \mathrm{~m}$.

Annual averages of temperature in the upper $(0-100 \mathrm{~m})$ layer evidence a marked interannual variability. Significant temperature differences among the years were clearly observed below $50 \mathrm{~m}$ depth (Anova, $P<0.05$, Fig. $3 \mathrm{~b}$ ). The period 1994-1998, if we except the year 1996, exhibits an overall warming trend. Year 1998 was the warmest year of the sampling period. The temperature averaged in the $(0$ $100 \mathrm{~m}$ ) layer could be represented by station 2 , it had an annual mean in 1998 which exceeded the mean of all 6 years by more than $0.7{ }^{\circ} \mathrm{C}$. The monthly temperature time series (Fig. 2a) show that excepting 1996 this warming was mainly due to a milder winter from 1994 to 1998. To a large extent, the air temperature in winter seems to account for this warming (Fig. 3a). As for water temperature, a warming trend is evident between 1994 and 1998 if we except cold year 1996. As a matter of fact, a high correlation coefficient was observed between air and water temperature $\left(r^{2}=0.63\right.$;
$P<0.05$, Fig. 4a) which strongly suggests that the interannual variability of the temperature in most of the water column was principally controlled by the winter mixing conditions. Summer heating plays a secondary role because it varies little from year to year and only affects the upper water column.

Salinity monthly time series at 0 and $50 \mathrm{~m}$ are highly correlated whereas the time series at $100 \mathrm{~m}$ had a different behavior (Fig. 2b). This illustrates the fact that the upper layer was mainly driven by surface waters of Atlantic origin which hardly extend below $50 \mathrm{~m}$. Thus, the upper $50 \mathrm{~m}$ layer had its own dynamics, likely energetic, while the deep layer was likely more steady. No seasonal cycle was evident in salinity. Monthly fluctuations dominated the signal at all three stations and principally in the upper $50 \mathrm{~m}$. Unlike temperature which is strongly driven by the local oceanatmosphere interaction, salinity is a good indicator of the origin of the water mass present in the area, allowing us to define conclusions with regard to the thermohaline circulation. The observed significant mesoscale oscillations is the consequence of the location of the Mallorca Channel in the highly fluctuating boundary region between southern and northern waters: the Balearic Front. Mesoscale fluctuations were modulated by an interannual signal (Anova, $P<0.05$; Fig. 3c). Low salinity waters, 37.5 on average, reached the 


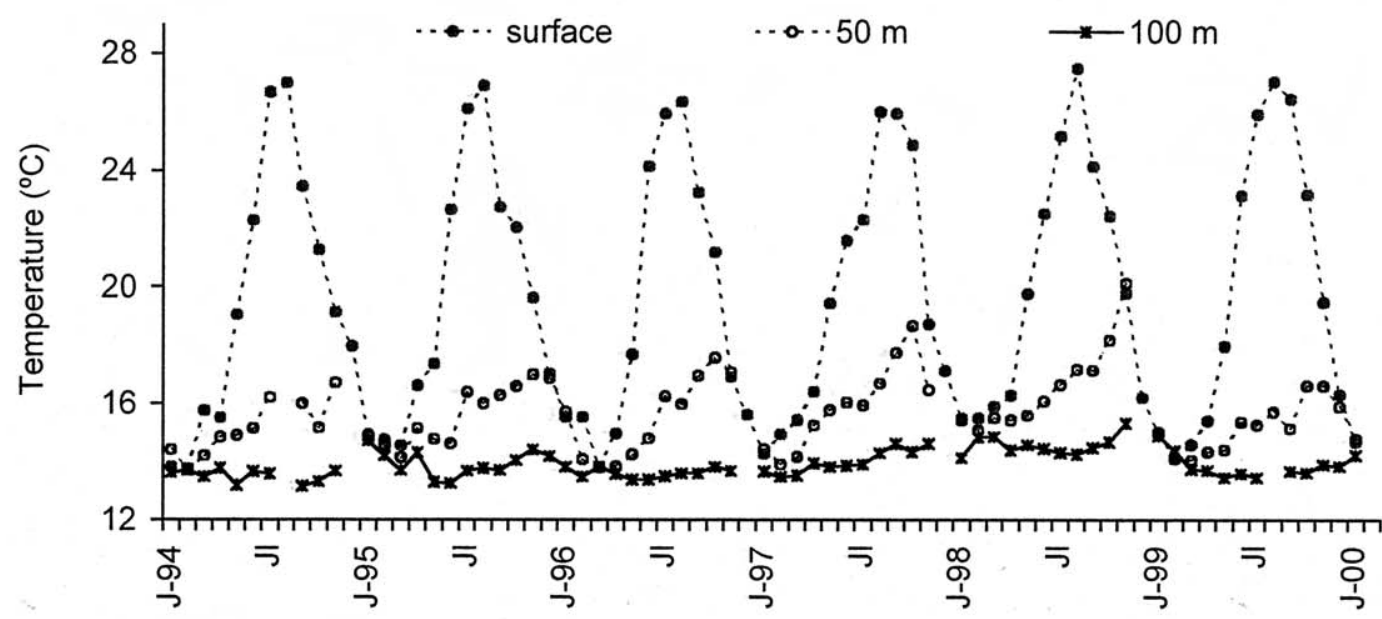

a
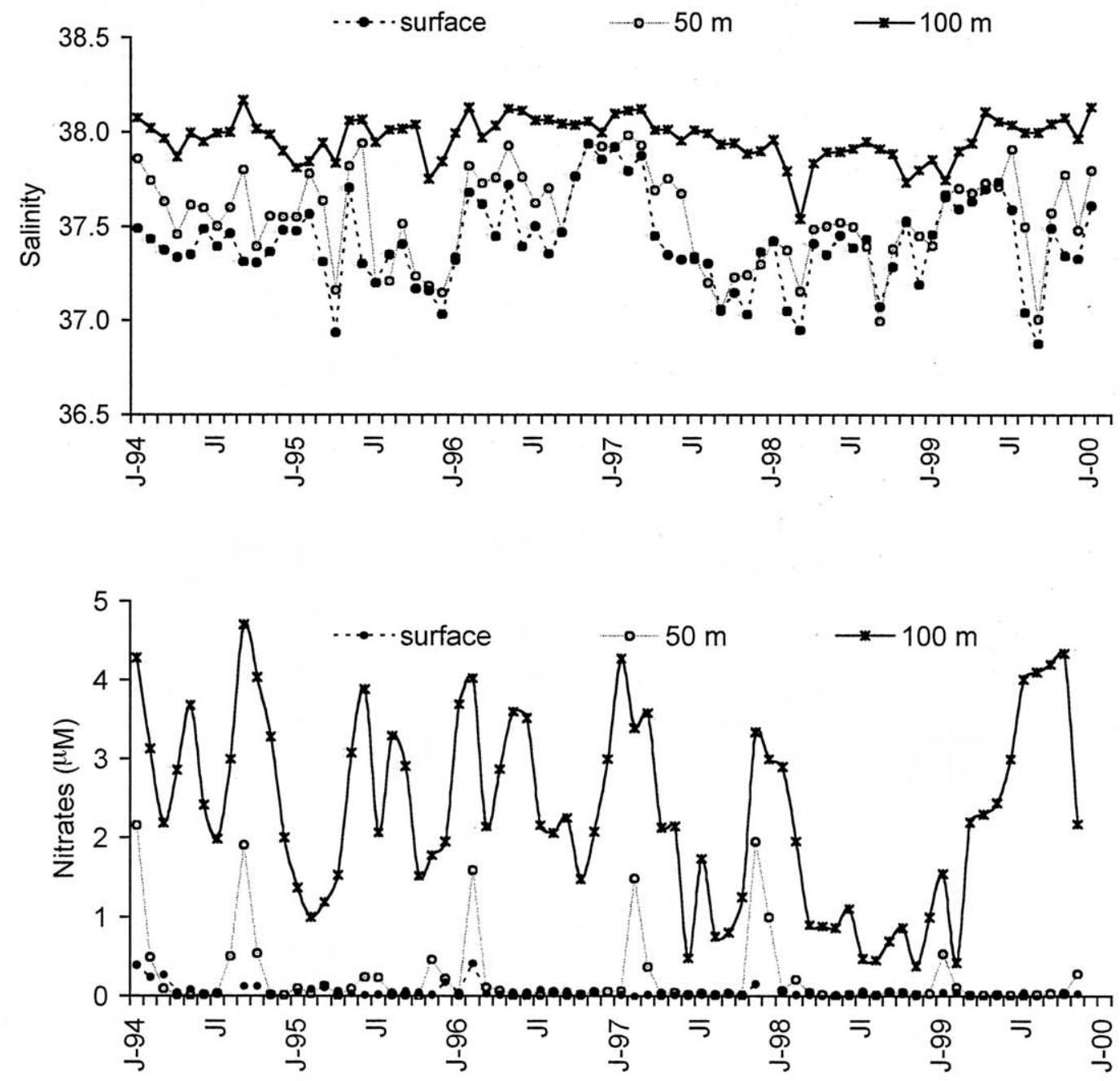

Fig. 2. Monthly time series at 0,50 and $100 \mathrm{~m}$ depth of (a) temperature $\left({ }^{\circ} \mathrm{C}\right),(\mathrm{b})$ salinity and, (c) nitrates concentrations ( $\left.\mu \mathrm{M}\right)$ during the period of study at station 3 .

study area during 1995. Years 1996 and the first half of 1997 were characterized by the presence of salty waters of northern origin, 37.7 on average in the $(0-100 \mathrm{~m})$ layer, while the second half of 1997 and year 1998 were characterized again by fresher waters of Atlantic origin, 37.5 on average. These fresher waters of southern origin were also warm, which may 

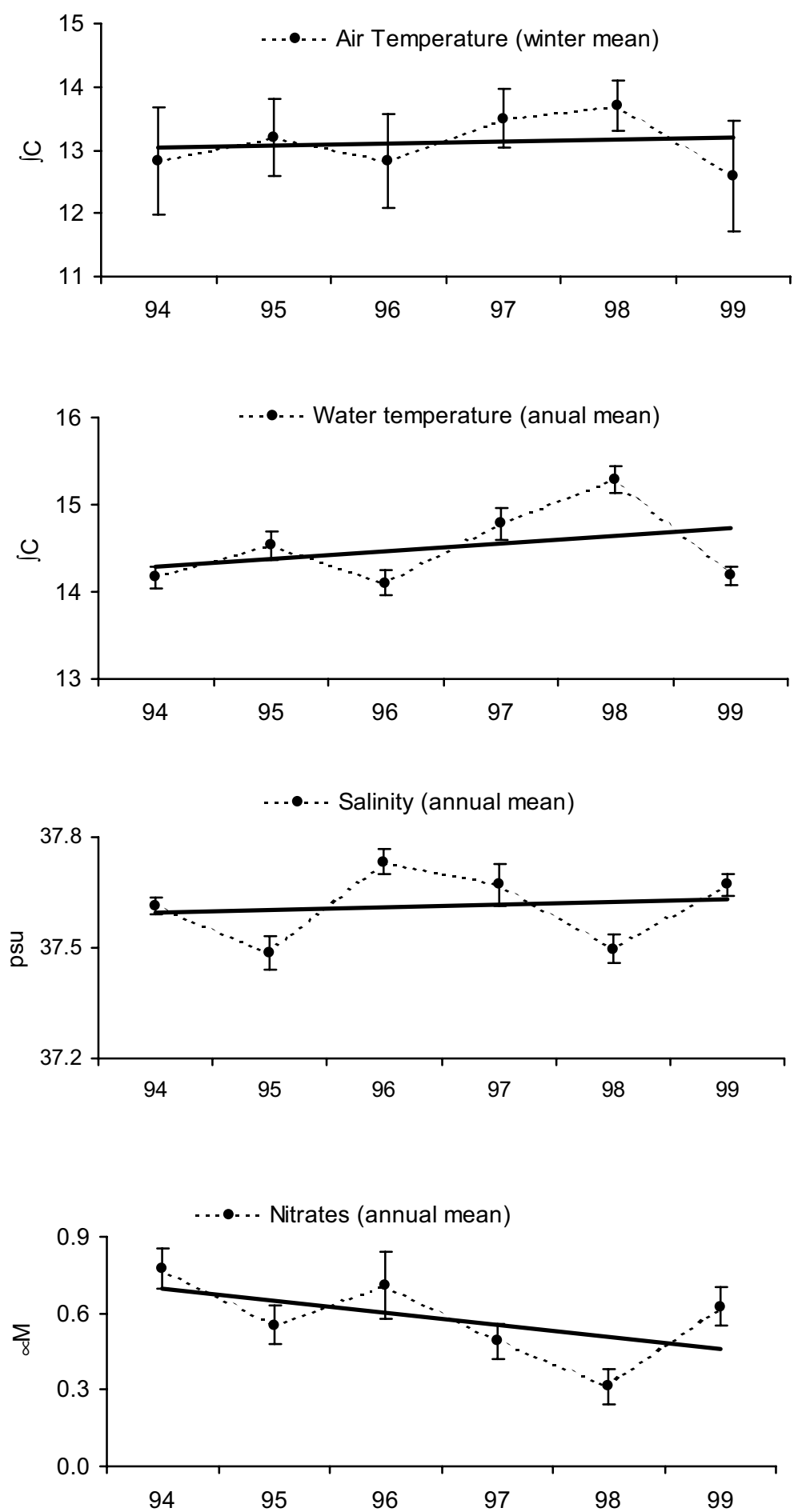

Fig. 3. Mean annual values and linear trends of (a) air temperature (winter months), (b) sea water temperature at $75 \mathrm{~m}$ depth, (c) salinity and (d) nitrates concentrations at station 2 .

have contributed to the water warming trend described above. The correlation coefficient between water temperature and salinity in the upper layer up to $100 \mathrm{~m}$ depth $\left(r^{2}=0.30 ; P<0.05\right)$ partly supports this hypothesis (Fig. $\left.4 \mathrm{~b}\right)$. In addition, it is interesting to note that low salinity was associated with mild winter atmospheric conditions (1995 and 1998) while high salinity was associated with more severe winters (years 1994, 1996 and 1999) (compare Fig. 3c, a). This reflects the fact that cold stormy weather in the western Mediterranean favor the southward spread of northern waters while milder winter climatic conditions allow for the northward spread of waters of recent Atlantic origin. In summary, salinity measurements show that not only local atmospheric conditions but also advective pro- 

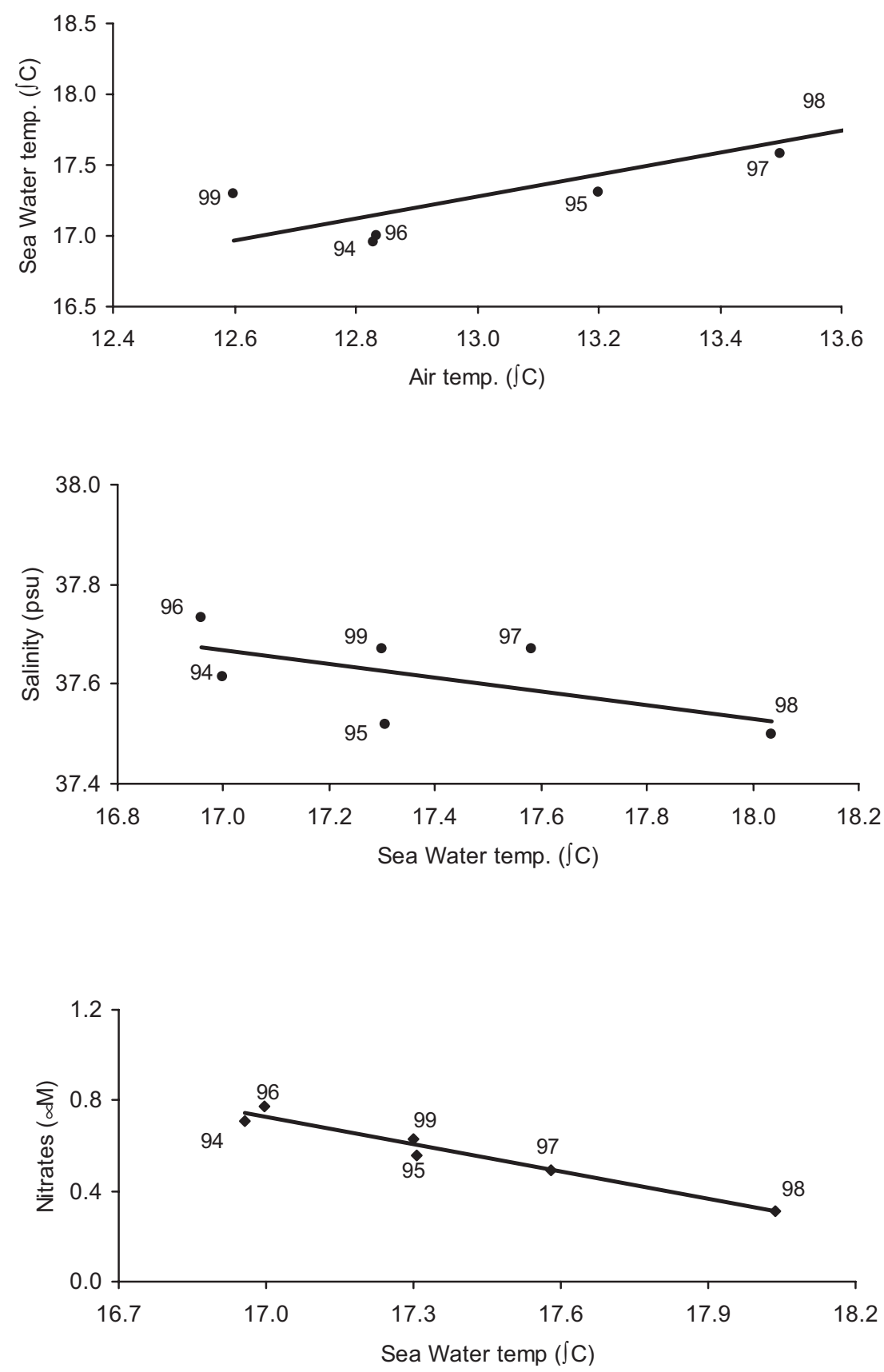

Fig. 4. Scattered plots and regression lines for annual means of (a) water temperature vs. air temperature, (b) salinity vs. water temperature and (c) nitrates concentration vs. water temperature at station 2 .

cesses, that is water mass circulation, have to be taken into account when considering the ocean temperature and salinity off Mallorca.

Nitrates do not present an obvious seasonal cycle but exhibit a strong signal (Fig. 2c). At surface, trace values $(<0.1$ $\mu \mathrm{M}$ ) were found all along the year. At $50 \mathrm{~m}$, there were also very low concentrations during almost all the year but peak values $(>1 \mu \mathrm{M})$ were recorded in the winter mixed layer especially in January. At $100 \mathrm{~m}$, nitrates concentrations were significantly enhanced. Interannual variations existed (Anova, $P<0.05$, Fig. 3d) which paralleled those of temperature. A significant correlation coefficient $\left(r^{2}=0.95 ; P<0.01\right)$ was found between both variables (Fig. 4c). Thus, a clear decrease in nitrates was associated with the marked warming during 1994-1998. There are two reasons for this high anticorrelation. The first one is that locally, cold stormy winters favored the entrainment of deep nitrates into the surface mixed layer. The second one is that cool waters proceeding from the northern Mediterranean into the study area are more nutrient rich because of windy conditions than less mixed waters of southern origin.

The three variables, water temperature, salinity and nitrates concentrations were grouped together in a cluster analysis of every value (Fig. 5). The result mostly reflects the 


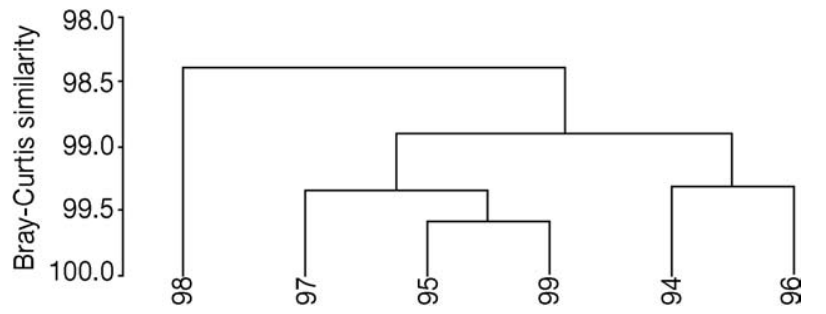

Fig. 5. Dendrogram for hierarchical clustering of samples from 1994 to 1999 when considering water temperature, salinity and nitrates concentrations at the three stations, based on the Bray-Curtis similarity matrix and squared root data transformation.

water temperature data. Year 1998 is diagnosed as a year with higher temperature, low salinity and low nitrates concentrations. Years 1995, 1997 and 1999 are grouped as cool years, and 1994 and 1996 as cold years with high nitrates concentrations.

\subsection{Zooplankton variability}

Fig. 6 shows the abundance variation of the main zooplankton groups during 1994-1999. Significant differences were found between the zooplankton abundance sampled at the neritic station and those sampled at deeper stations, 2 and 3 (Anova, $P<0.05$ ). Those to these latter stations gave very similar results without significant differences between them. The onshore gradient in abundance was due to the higher numbers of the main zooplankton groups at station 1 , such as copepods, appendicularians, cladocerans and meroplankton larvae (Fig. 6a). All of them exhibited a high decreasing trend in their abundances $(33 \%, 34 \%$ and $40 \%$, copepods, appendicularians, cladocerans and meroplankton larvae, respectively) from the most neritic to deeper station (st. 2) and very small differences on going further offshore. No significant differences were found considering the zooplankton biomass among the stations (Anova, $P>0.05$ ) and high correlation was observed between the biomass and the total abundance of zooplankton $\left(r^{2}=0.51, P<0.05\right)$. The low annual biomasses $\left(5.56,4.96\right.$ and $5.02 \mathrm{mg} \mathrm{m}^{-3}$ ) and moderated annual abundances $\left(1021,683\right.$ and $634 \mathrm{ind}^{-3}$ ) indicated the small size of the zooplanktonic organisms representing the area. On average, copepods constituted the most abundant group (54\%), followed by appendicularians (17\%), cladocerans and meroplankton larvae (13\%). Minor groups, such as doliolids (5\%), siphonophors (4\%), chaetognaths (3\%) and pteropods (1\%), did not exhibit a clear cross-shelf gradient (Fig. 6b). Only ostracods showed more abundance at deeper stations (Fig. 6c).

Monthly fluctuations in zooplankton abundance were present all year long reflecting the complex response of zooplankton to the biological and environmental conditions. These mesoscale fluctuations are evident with the most abundant groups and with total zooplankton abundance (Fig. 7). The zooplankton decrease observed on going offshore was clear (33\% from coastal to deeper stations), but the copepods dominated similarly, in their relative abundance, at all the stations throughout the year. Only during summer, a decrease was observed due to the higher abundance of cladocerans. Among this patchy pattern, seasonal cycles were, however, evident. Copepods exhibited higher abundance during winter and spring and more irregular fluctuations were observed for appendicularians, these did not perform clear seasonality. This seasonal oscillation was particularly clear for the cladocerans which were in the area from March to October but reached maximum numbers during summer when the maximum stratification of the upper waters was observed (JuneAugust at st. 1 and 2 and later summer at st. 3). Meroplankton larvae were only important at the coastal station during spring and summer (April-August). Doliolids did not show differences among the stations and they were more numerous during spring. Siphonophores were important mainly in winter, pteropods were more abundant in fall and ostracods during winter months. No obvious seasonal trend was present in the records of chaetognaths. As the major group, copepods were monthly averages and separately represented in order to filter out the high-frequency noise. They dominated the zooplankton assemblages with a clear decreased in abundance further offshore. The obtained mean annual cycle at station 1 (Fig. 8a) shows that on average a maximum is observed in May while two secondary maxima occurred in February and October. The lowest abundance was observed in late summer and late autumn. This seasonal cycle was also clear offshore but with smaller fluctuations (Fig. 8b). Very similar fluctuations as for copepods were observed in the seasonal cycle of total zooplankton abundance (Fig. 9). According to that, the total zooplankton population decreased throughout the year, from January to December, reflecting quite well the seasonal variation of the copepods population.

Year to year variability was observed in the main groups of zooplankton (copepods, appendicularians, cladocerans and meroplankton larvae) (Fig. 6a). It was characterized by an overall decrease in abundance for same groups from 1994 to 1999 . This decrease was particularly evident in the mean spring-summer populations of cladocerans, meroplankton larvae and siphonophores, which significantly declined throughout the 6 years of the study. The large peak values $\left(>1200\right.$ ind $\mathrm{m}^{-3}$ ) of the copepods population occurring in spring in 1994-1996 did not exist anymore during 19971999. The total yearly averaged abundance illustrates well this general decrease in both zooplanktonic studied indices, numerical abundance and biomass (Fig. 10). From 1100 ind $\mathrm{m}^{-3}$ in 1994, it fell down to 750 ind $\mathrm{m}^{-3}$ in 1999 . Year 1998 was the year during which the mean abundance was the minimum (600 ind $\mathrm{m}^{-3}$ ) and the lowest biomass was reached. Fitted regression lines were found between both indices (numerical abundance and biomass) at coastal and oceanic stations $\left(n=72 ; r^{2}=0.51, P<0.01\right)$

$$
\begin{aligned}
& y=49 x+172 \\
& y=78 x+278
\end{aligned}
$$

where $y$ represented the abundance (as individual $\mathrm{m}^{-3}$ ) and $x$ the biomass ( $\mathrm{mg}$ dry weight $\mathrm{m}^{-3}$ ). 

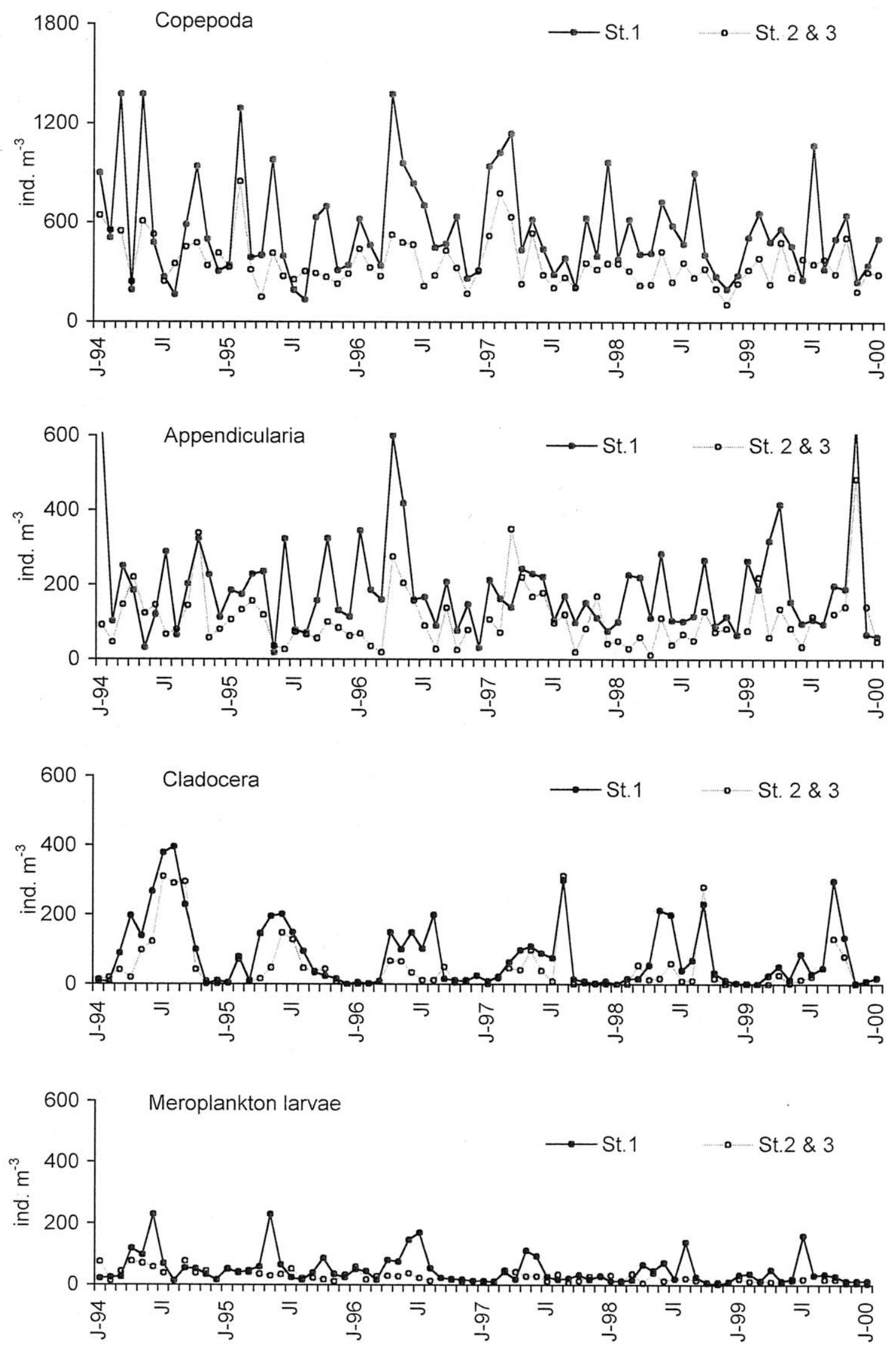

Fig. 6. Monthly time series of the zooplankton group abundance.

(a) Copepods, appendicularia, cladocera and meroplankton larvae (as ind $\mathrm{m}^{-3}$ ) at the neritic (st. 1) and offshore stations (stations 2 and 3 averaged). 

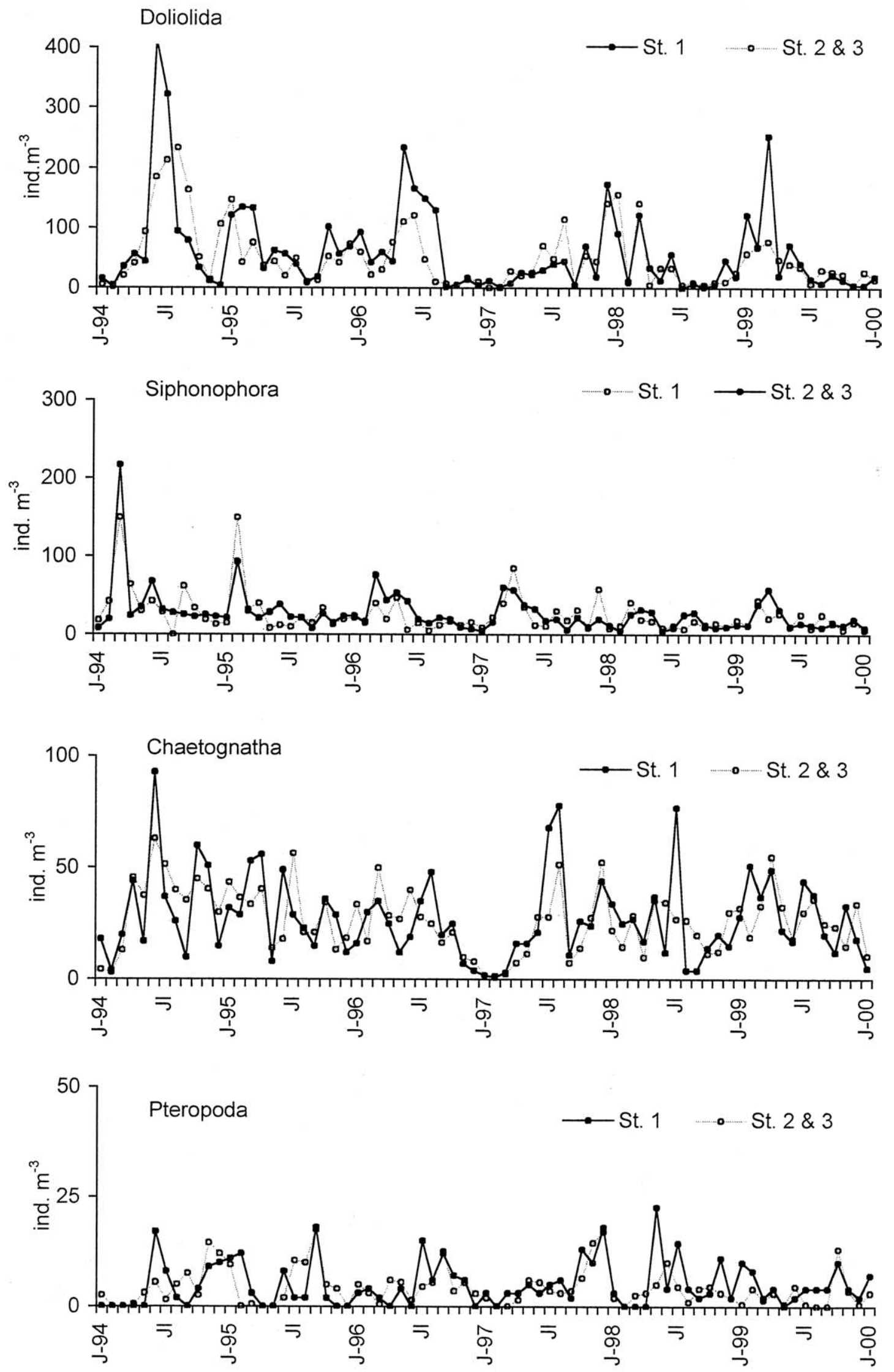

Fig. 6 (continued).

(b) Doliolida, siphonophora, chaetognatha and pteropoda at the neritic and offshore stations (stations 2 and 3 averaged). 


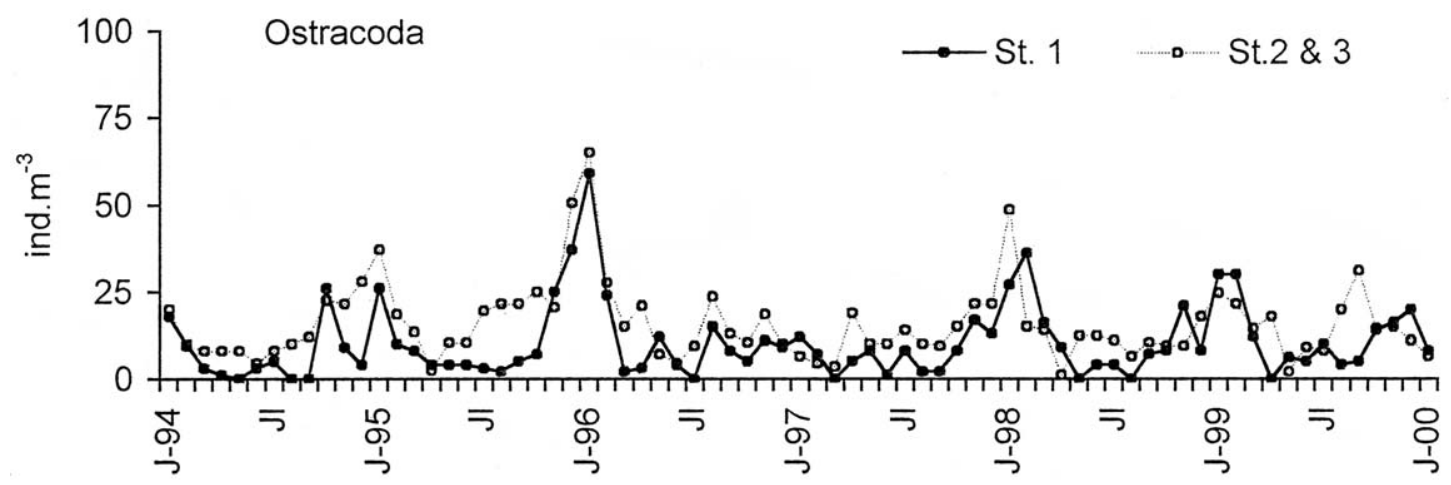

Fig. 6 (continued).

(c) Ostracoda at the neritic and offshore stations (stations 2 and 3 averaged).

\section{Discussion}

The data presented provide a basic information of the zooplankton community during an important period of time in the upper waters off Mallorca island. The strategic situation of the island allowed us to observe a clear neritic-ocean gradient of the zooplankton abundance and its temporal variability, mainly due to the small environmental shelf. The decreasing of the zooplankton abundance on going offshore seems to be usually observed (Estrada et al., 1985). However, it was not always the same in some open sea areas of the western Mediterranean Sea (Kouwenberg and Razouls, 1990; Gaudy and Champalbert, 1998). In our study, it was clear for copepods, appendicularians, cladocera and meroplankton larvae but not for other zooplankton groups.

The zooplankton data collected during the 6 studied years showed annual low biomasses and moderated abundances, comparable to poor areas of the Eastern Mediterranean Sea (Siokou-Frangou, 1996; Mazzocchi et al., 1997) and much lower comparing other areas of the Western Mediterranean (Rodriguez, 1983; Sabates et al., 1989; Gaudy and Champalbert, 1998). Nevertheless, poor areas may have notable concentrations of small zooplankton during some periods of the year (Razouls and Kouwenberg, 1993). The importance of the small size of the zooplankton community observed in the area has also been notified recently in other neighboring areas (Calbet et al., 2000). Seasonally, two peaks of abundance (winter or spring and autumn) seem to be the typical pattern in the Mediterranean (Scotto di Carlo and Ianora, 1983; Siokou-Frangou, 1996) and whereas in coastal areas the late spring peak takes importance (Mazzocchi and Ribera d'Alcalá, 1995) in open sea areas the winter peak takes more relevance (Gaudy and Champalbert, 1998). In the Balearic Sea, three peaks were almost present with a decreasing coast-

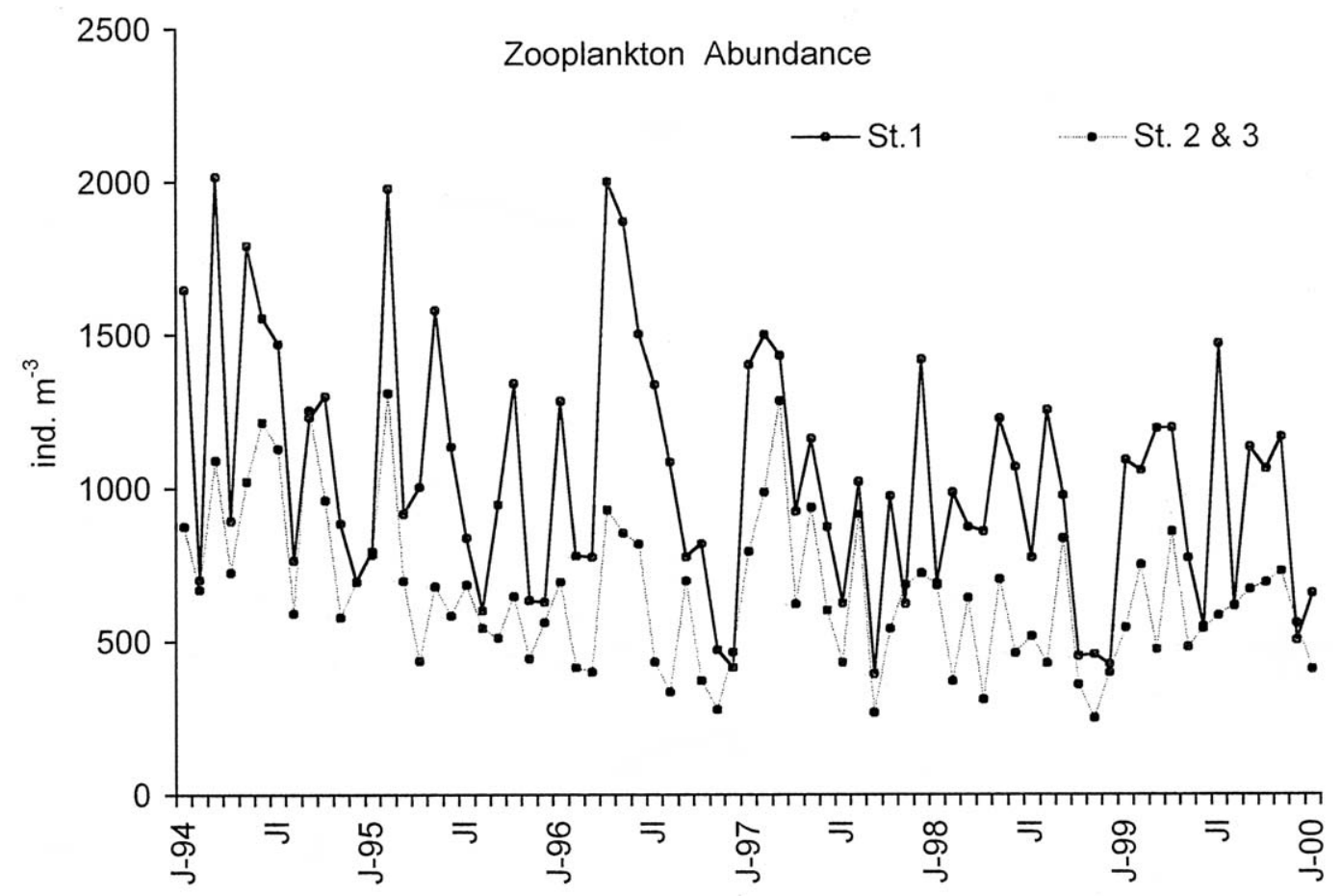

Fig. 7. Monthly time series of total zooplankton abundance (as ind $\mathrm{m}^{-3}$ ) at the neritic (st. 1) and offshore stations (stations 2 and 3 averaged). 
Station 1

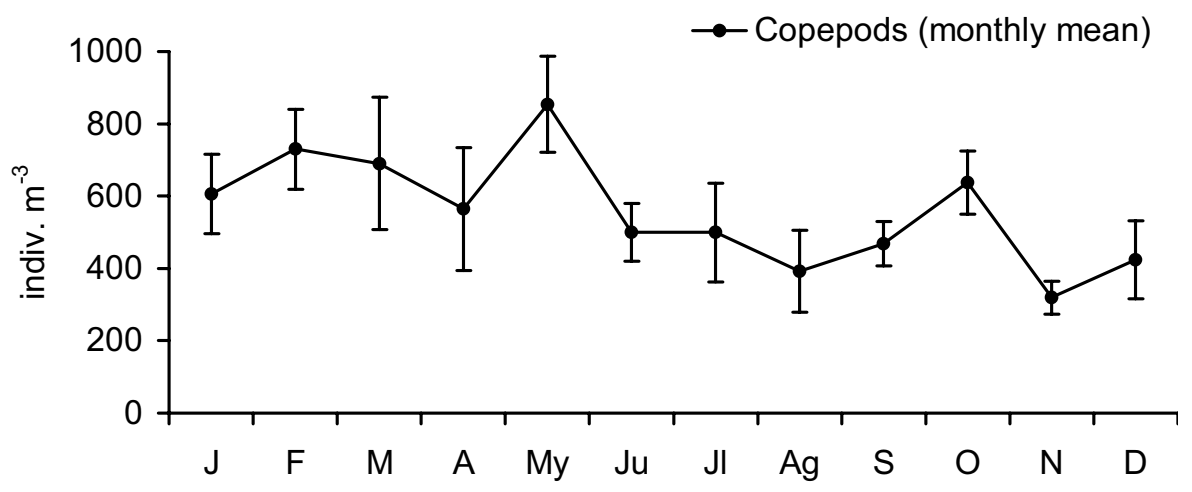

Station $2 \& 3$

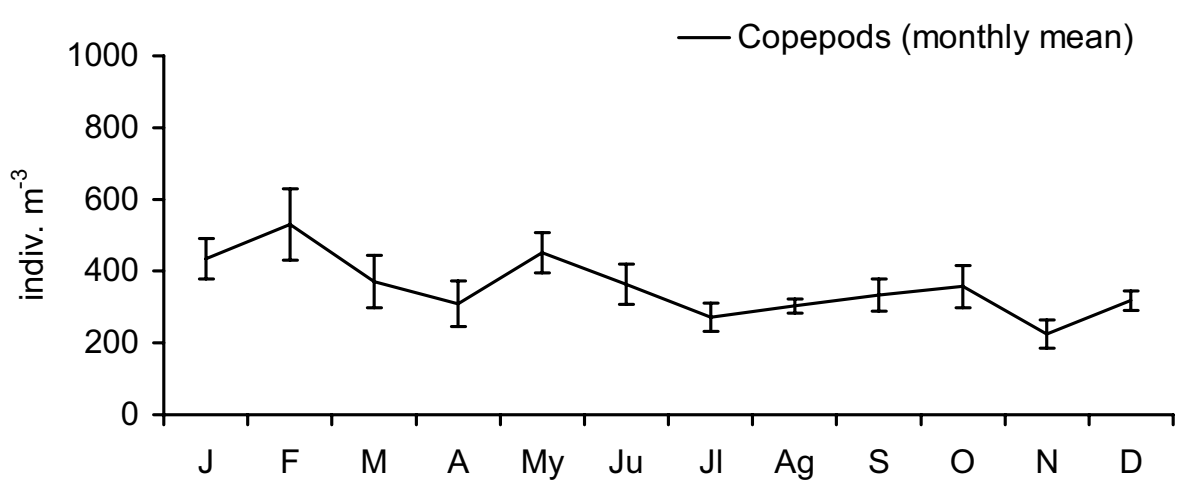

Fig. 8. The seasonal cycle of copepods abundance (as ind $\mathrm{m}^{-3}$ ) for the period 1994-1999 at the neritic station and at offshore stations (stations 2 and 3). Vertical bars show the standard error.

\section{Seasonal zooplankton variation}

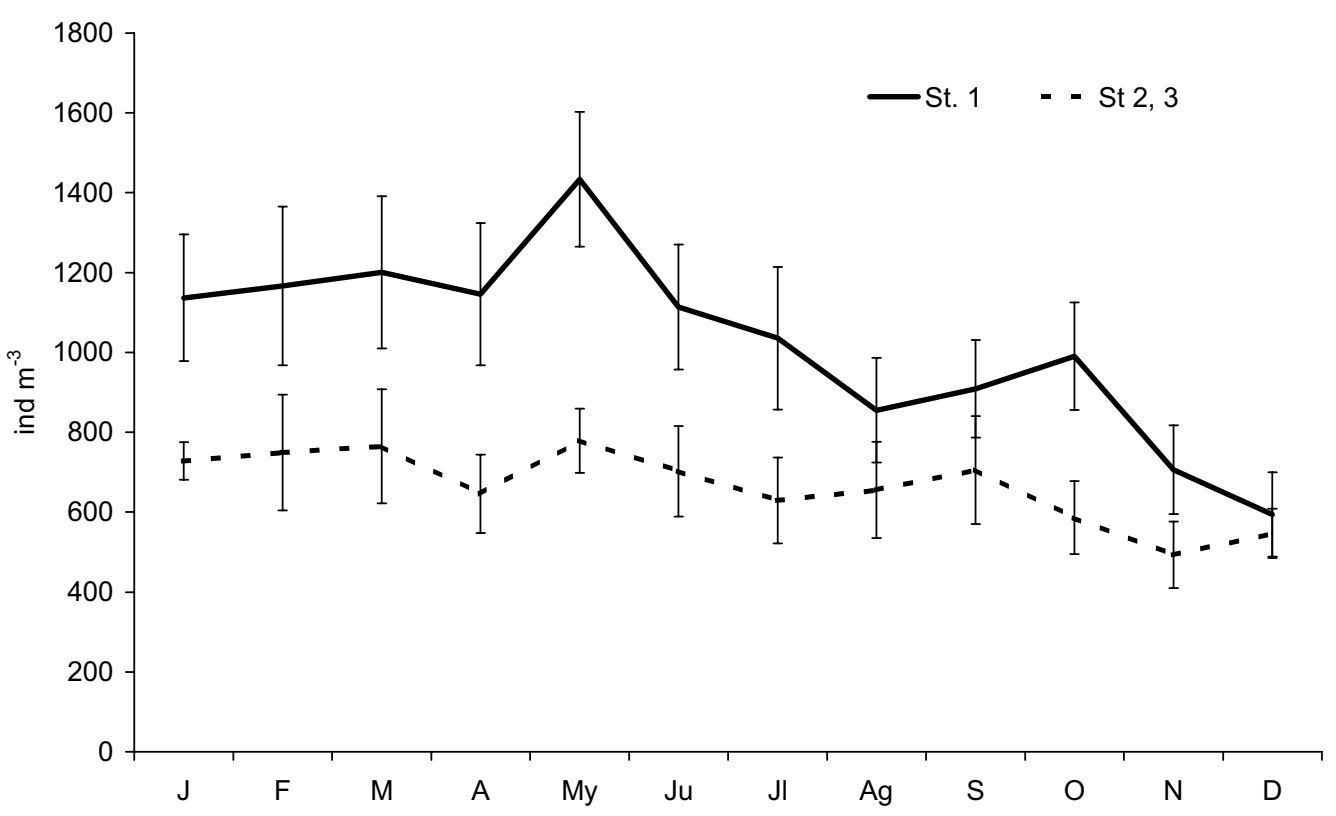

Fig. 9. The seasonal cycle of total zooplankton abundance (as ind $\mathrm{m}^{-3}$ ) for the period 1994-1999 at neritic (st. 1, solid line) and offshore stations (stations 2 and 3 averaged, dashed line). Vertical bars show the standard error. 


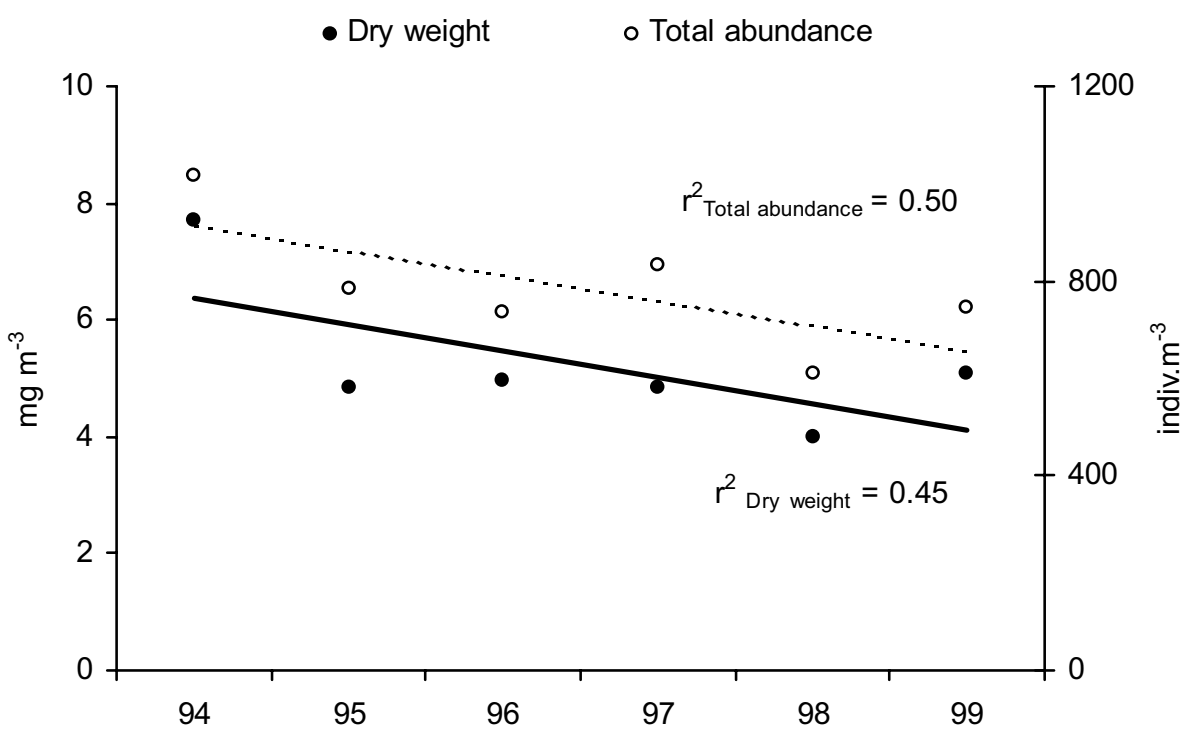

Fig. 10. Annual means of total zooplankton abundance $\left(^{\wedge}\right)$ and biomass $(\bullet)$ and their linear trends during 1994-1999.

open sea gradient. The late spring peak was rather important in neritic and coastal areas and the winter peak in oceanic areas.

The seasonal cycle constitutes the most important periodic oscillation in the recorded zooplankton abundance. It explains much of the variance in time fluctuations. Generally speaking, maximum values of abundance were centered on the first 6 months of the year when waters were well mixed. However, some few groups increased when the waters were stratified, such as the cladocerans and meroplankton larvae. As a result, the total zooplankton abundance in waters of the Balearic Sea shows not very different pattern, in coastal and oceanic stations, with a clear gradient and maximum values in spring and winter and minimum values in fall, closer to oligotrophic areas of the Mediterranean Sea (SiokouFrangou, 1996).
An interannual decreasing trend is observed in zooplankton abundance, mainly reflected by the major zooplankton groups, such as copepods. In parallel, temperature increased during this period. The correlation obtained between the yearly averages of temperature and copepod abundance $\left(r^{2}=0.46\right)$ strongly suggests that the progressive depletion in zooplankton could be a response to the warming trend (Fig. 11). Similar results were found during a 30 year study in the California Current (Roemmich and Mc Gowan, 1995). Air temperature data show that this warming was mainly due to winters each time milder during 1994-1998 (except 1996). Mild weather conditions had two effects: they (1) reduced cooling by local mixing in winter and (2) spread of warm southern waters into the Mallorca channel.

With regard to the impact of local mixing in winter on zooplankton, our results agree with those of Estrada et al.

- Copepods Vs Temperature

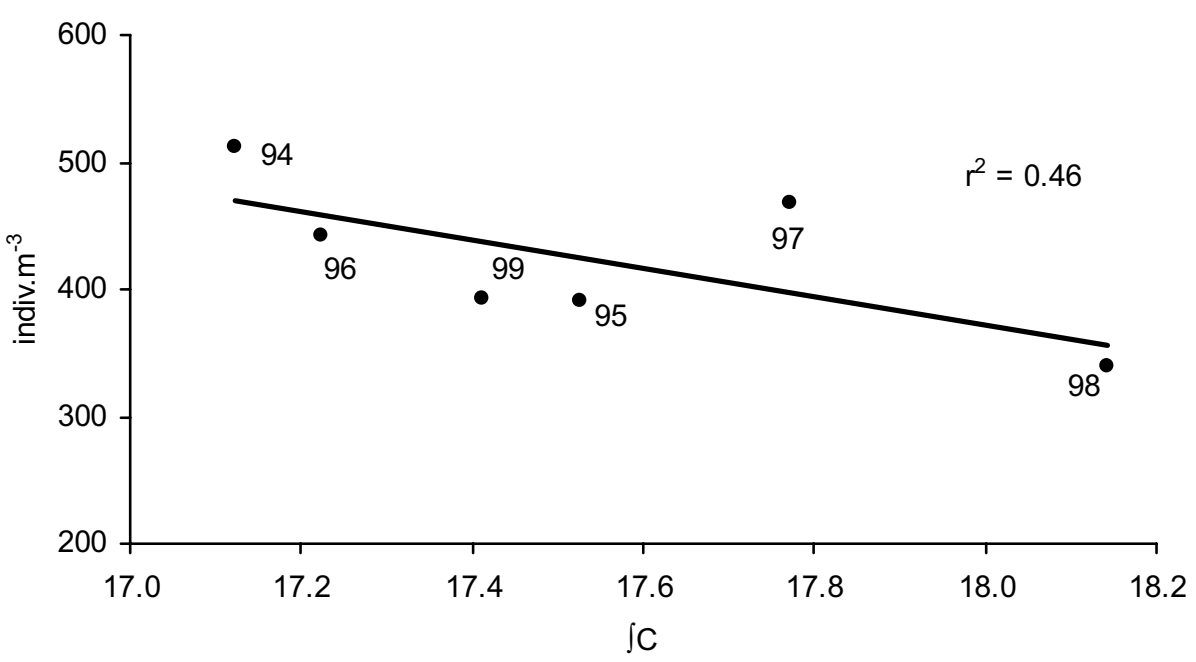

Fig. 11. Scattered plot of annual means of copepod abundance (as ind $\mathrm{m}^{-3}$ ) vs. temperature and its regression line. 
(1985) who showed that cold winters are usually more productive than mild winters. Enhanced winter mixing favors the entrainment of deep nutrients at the base of the surface mixed layer. This fertilization of the euphotic layer can be expected to increase primary and secondary production.

With regard to hydrographic data, we found that waters of southern and northern origin alternatively reached the Mallorca Channel and low salinity values characterized the arrival of southern waters of Atlantic origin during 1997-1998 (Pinot et al., 2002). These authors showed that during this period major inflows of Atlantic origin penetrated into the Mallorca Channel pushed by large, persistent eddies lying to the south of the Balearic Islands. These waters are more stratified and less rich in nutrients than the waters of northern origin because of differential wind-forced mixing. Thus, southern waters could severely limit primary and secondary productions. There could also be a link between the water mass present at the sampled stations and the zooplankton community structure.

The high-frequency fluctuations, which dominated the zooplankton record could have several origins. Mesoscale events such as eddies, fronts or filaments are known to be present in the area (Jansá et al., 1998) and they can favor plankton accumulation or production. Meteorological process events can affect drastically the zooplankton distribution. It is known for example that zooplankton stay at lower depths during day-time if cloudiness is high (Pinot and Jansá, 2001).

\section{Conclusions}

The data presented provide a basic information of the zooplankton community over 6-years period of time in relation to the environmental properties of the surface water in the Balearic Sea. For the first time, the seasonal cycle in the different zooplankton groups is assessed. A progressive decrease is diagnosed in zooplankton abundance over the study period. The parallel atmospheric warming trend, and the associated depletion in nutrients, appears as a likely candidate to explain it. There might be relation to the global warming in the marine ecosystem. We conclude that the dominant physical factor governing zooplankton abundance at large scale was the winter air temperature, a proxy for winter climatic conditions, which influenced the water temperature by local mixing and by driving oceanic advection into the channel. At smaller scales, it is likely that ocean and atmosphere mesoscale patterns (eddies) played a major role for the biology in the study area.

\section{Acknowledgements}

This research has been carried out in the framework of project 1007 "Time-series of oceanographic observations in the Balearic Islands", supported by the Instituto Español de Oceanografía. Our thanks go to the crew of $\mathrm{R} / \mathrm{V}$ "Odón de
Buén" and to all those who contributed to the cruises and laboratory work: M. Serra, D. Oñate and in particular L. Vicente for the analysis of zooplankton abundance and T. Amengual. J. Valencia has a grant from the Instituto Español de Oceanografía. But particularly the authors want to thank to the anonymous referees and to Dr. Santiago Hernández de León for their advises and suggestions in the improvement of the manuscript.

\section{References}

Armstrong, F.A.J., Sterns, R.C., Strickland, J.D.H., 1967. The measurements of upwelling and subsequent biological processes by means of technicon autoanalyzer and associated equipment. Deep-Sea Res 14, 381-389.

Baranovic, A., Solic, M., Vucetic, T., Krstulovic, N., 1993. Temporal fluctuations of zooplankton and bacteria in the middle Adriatic Sea. Mar. Ecol. Progr. Ser. 92, 65-75.

Calbet, A., Garrido, S., Saiz, E., Alcaraz, M., Duarte, C., 2000. Annual zooplankton succession in coastal NW Mediterranean waters: the importance of the smaller size fractions. J. Plankt. Res. 23 (3), 319-331.

Christou, E.D., 1998. Interannual variability of copepods in a Mediterranean coastal area (Aegean Sea). J. Mar. Syst. 15, 523-532.

Colebrook, J.M., 1978. Continuous plankton records: zooplankton and environment, north-east Atlantic and North Sea, 1948-1975. Oceanol. Acta 1, 9-23.

Colebrook, J.M., 1985. Sea surface temperature and zooplankton, North Sea, 1948 to 1983. J. Cons. Per, Int. Explor. Mer. 42, 179-185.

Estrada, M., Vives, F., Alcaraz, M., 1985. Life and production in the open sea. In: Margalef, R. (Ed.), The Western Mediterranean. Pergamon Press, London, pp. 150-200.

Fernández de Puelles, M.L., Jansá, J., Gomis, C., Gras, D., Amengual, B., 1997. Variación anual de los principales parámetros oceanográficos y planctónicos en el Mar Balear. Bol. Inst. Esp. Oceanogr. 13 (1), 12-26.

Font, J., Salat, J., Tintore, J., 1988. Permanent features of the circulation in the Catalan sea. In: Minas, H.J., Nival, P. (Eds.), Oceanol. Acta, 9, pp. 51-57 Oceanography Pelagic Mediterranean.

García, E., Tintoré, J., Pinot, J.M., Font, J., Manriquez, M., 1994. Surface circulation and dynamic of the Balearic Sea. Seasonal and interannual variability of the Western Mediterranean Sea. Coast. Estuar. Stud. 46, 73-91.

Gaudy, R., 1985. Features and peculiarities of the zooplankton community from the western Mediterranean. In: Moraitou Apostolopoulou, M., Kiartsis, V. (Eds.), Mediterranean Marine Ecosystems. Plenum Press, New York, USA, pp. 279-302.

Gaudy, R., Champalbert, G., 1998. Space and time variations in zooplankton distribution south of Marseilles. Oceanol. Acta 21 (6), 793-802.

Jansá, J., López-Jurado, J.L., Morillas, A., Amengual, B., 1998. Seasonal and mesoscale variability of biological and chemical parameters related to the hydrodynamics of the Ibiza Channel. Bol. Inst. Esp. Oceanogr. 14 (1 and 2), 31-47.

Kouwenberg, J., Razouls, C., 1990. The incidence of environmental factors on the evolution of copepod populations in the Gulf of Lion during the period 1986-1988 in comparison with the period 1957-1964. Bull. Soc. Zool. 115, 23-36.

Lovegrove, T., 1966. The determination of the dry weight of plankton and the effect of various factors of the values obtained. In: Barnes, R. (Ed.), Some Contemporary Studies in Marine Science. Allen, G., Unwin, London, pp. 462-467.

Mazzocchi, M.G., Ribera d'Alcalá, M., 1995. Recurrent patterns in zooplankton structure and succession in a variable coastal environment. ICES J. Mar. Sci. 52, 679-691.

Mazzocchi, M.G., Christou, E., Fragopoulu, N., Siokou-Frangou, I., 1997. Mesozooplankton distribution from Sicily to Cyprus (eastern Mediterranean): general aspects. Oceanol. Acta 20 (3), 521-535. 
Pinot, J.M., Jansá, J., 2001. Time variability of acoustic backscatter from zooplankton in the Ibiza Channel (western Mediterranean). Deep-Sea Res. I 48, 1651-1670.

Pinot, J.M., Lopez-Jurado, J.L., Riera, R., 2002. The CANALES experiment (1996-1998). Interannual, seasonal and mesoscale variability of the circulation in the Balearic Channels. Progr. Oceanogr. 55 (3-4), 335370

Postel, L., Fock, H., Hagen, W., 2000. Biomass and abundance. In: Harris, R.P., Wiebe, P.H., Lenz, J., Skjodal, H.R., Huntley, M. (Eds.), ICES Zooplankton Methodology Manual. Academic Press, London, pp. 83192

Razouls, C., Kouwenberg, J., 1993. Spatial distribution and seasonal variation of mesozooplankton biomass in the Gulf of Lions. Oceanol. Acta 16 (4), 393-401.
Rodriguez, J., 1983. Estudio de la comunidad planctónica nerítica en el mar de Alboran: II Ciclo de zooplancton. Bol. Inst. Esp. Oceanogr. 1, 19-44.

Roemmich, D., Mc Gowan, J., 1995. Climatic warming and the decline of zooplankton in the California Current. Science 267, 1324-1326.

Sabates, A., Gili, J., Pages, F., 1989. Relationship between zooplankton distribution, geographic characteristic and hydrographic patterns off the Catalan Coast. Mar. Biol. 103, 153-159.

Scotto di Carlo, B., Ianora, A., 1983. Standing stocks and species composition of Mediterranean zooplankton. UNESCO Rep. Mar. Sci. 20, 59-69.

Siokou-Frangou, I., 1996. Zooplankton annual cycle in a Mediterranean coastal area. J. Plankt. Res. 18, 2803-2823.

Vives, F., 1966. Zooplancton nerítico de las aguas de Castellón Mediterráneo Occidental. Inv. Pesq. 30, 49-166. 